Article

\title{
Investing in College Education: Debtors, Bettors, Lenders, Brokers
}

\author{
Ellen Messer-Davidow
}

Department of English, University of Minnesota, Twin Cities, Minneapolis, 55455 MN, USA; emd@umn.edu

Academic Editor: Ronald Strickland

Received: 18 January 2017; Accepted: 31 March 2017; Published: 10 April 2017

\begin{abstract}
Federal and private lenders have issued college student loans, now rising above $\$ 1.3$ trillion nationwide and, to gain revenues for continued lending, sell them to securitizers who in turn bundle them into asset-backed securities. This paper argues that the magnitude of debt, high rates of default and forgiveness, and uncertain long-term repayment by borrowers facing lackluster job opportunities replicate the techniques of neoliberal financialization (subprime mortgages, securitization, overstocked housing market) that triggered the 2008 economic meltdown.
\end{abstract}

Keywords: college student debt; Federal Direct Loan Program; loan industry; financialization; loan securitization; profit from debt

"Debt is the lifeblood of finance; it is where the financial industry makes its money."

$$
\text { —(Foroohar 2016, p. 9) }
$$

For nearly three decades the topic of college student loan debt circulated as an undercurrent in academic fields-economics, sociology, education, and especially progressive critiques of the neoliberal university for embracing corporate capitalism's fiscal models, management techniques, and contingent labor. Then it burst onto the national scene with media stories about toxic debt-the role of subprime mortgages and home foreclosures in the 2007-2008 economic crisis, the Occupy Wall Street Movement protests against many forms of injustice, the Obama Administration's tweaks to ease student loan crunches, and the 2016 presidential election. As always happens when an issue is politicized, the candidates and their supporters balkanized into camps that played the blame game, criticizing colleges for soaring tuition, the federal loan program for its complex application and repayment processes, borrowers for their lack of financial literacy, and Congress for too little or too much action. By then over 40 million Americans carrying college loans and the millions more who heard about loans were extremely worried that this debt might not only ruin lives but also trigger an economic spasm on the magnitude of the last one.

In Games of Loans: The Rhetoric and Reality of Student Debt, Beth Akers and Matthew M. Chingoes offer reassurance:

This narrative [of a student loan crisis] quickly withers in the face of even rudimentary evidence on the student lending market in the United States. Student loans are too small of a market and too isolated from the private sector to cause anything close to the kind of economic damage suggested by the comparisons to the housing crisis. Massive student loan defaults could make a small dent in the federal budget, but they can't take down the U.S. economy (Akers and Chingos 2016, p. 63).

In this article, I argue that Akers and Chingos couldn't be more wrong. First of all, the numbers by themselves are scary. Student loan debt, now at $\$ 1.3$ trillion, does not include college costs that students pay with scholarships, credit cards, and family aid. The $\$ 1.3$ trillion, which is slightly larger 
than the $\$ 1.2$ trillion in subprime mortgage debt that triggered the last meltdown, is not negligible in an economy that also has $\$ 8.4$ trillion in mortgage debt, $\$ 1.2$ trillion in auto loan debt, and $\$ 780$ billion in credit card debt but a GDP of about $\$ 18$ trillion. Second, it's hard to tell exactly what is going on within the pool of college loan debt because the granular data, as financial journalists call them, are spotty owing to the government's lax reporting requirements for private and federal lenders. Third and most importantly, the college student loan industry is repeating the dangerous financialization strategies that caused the 2007-2008 meltdown.

To make my counter-argument, I review the restructuring of the financial industry, the subprime fiasco, and derivatives that extract profit from debt. Next I explain college student loans, connecting this loan debt to the graduates' employment prospects and showing how racial minorities and lower-income whites are particularly disadvantaged in the education-to-employment pipeline. Finally I return to the neoliberal financial architecture that enabled the extraction of profit and the question of whether the U.S. can make good on its backstopping of college student loan defaults. The story I tell does not focus on individuals-careless lenders, greedy securitizers, and students indentured to lifetime debt; it focuses on the economic structure put in place by neoliberal policy and predatory capitalism.

\section{Restructuring the Financial Industry}

Until about 1980, financial institutions were disaggregated into sectors with governmentally limited activities. Community-based savings and loans (S\&Ls) provided customers with deposit (savings) accounts and home mortgages, the depository revenues funding residential mortgages collateralized by the homes. The standard mortgage agreement required the borrower to provide a significant percentage of the home's purchase price and repay the loan over 10 to 20 years at a fixed interest rate. Commercial banks, ranging from small-town institutions chartered by the state to national ones regulated by the federal government, provided checking and savings accounts, personal and business loans, certificates of deposit, and currency exchange. Local and national investment firms handled securities transactions. All of these institutions served middle- and upper-income clients, leaving "unbanked" racial minorities and low-income whites to cash paychecks at check-cashing stores, make retail purchases on lay-away, obtain emergency cash from pawn shops, and transmit funds through Western Union, all charging hefty fees.

New Deal policies and industry practices persisting into the 1980s built discrimination into credit markets. During the Great Depression, Adam Gordon explains, "home mortgage foreclosures rose from sixty-eight thousand per year in 1926 to one thousand homes per day in early 1933, when half of all mortgages in the United States were in default" (Gordon 2005, p. 192). Congress enacted the Home Owners' Loan Act of 1933, which established the Home Owners' Loan Corporation (HOLC) to collect on defaulted loans, and the National Housing Act of 1934, which established the Federal Housing Administration (FHA). In turn the FHA imposed a surcharge to indemnify lenders against defaults and relaxed various regulations to stimulate the mortgage market (Gordon 2005, pp. 192-93); by mid-century it "provided almost half of all U.S. mortgage-funding ... and guaranteed a portion of the remaining mortgages" (Dymski 2009, p. 155). The FHA's scope in the loan market broadened the reach of the discriminatory property rating scheme it borrowed from the Home Owners Loan Corporation, which assigned an "A" to neighborhoods with single family homes, white residents, and usually suburban locations, but gave a " $\mathrm{D}$ " (colored red) to those with mixed residential and commercial properties, racial minority residents, and urban locations. ${ }^{1}$

1 Gordon attributes the HOLC's rating scheme to economist Homer Hoyt's devolutionary model of residential space: "In this model, neighborhoods started out new and white. Over time, housing stock deteriorated, and the neighborhood transitioned from white Protestant to Jewish and finally black" (Gordon 2005, p. 208). 
This racialized scheme impacted potential homeowners. By taking out conventional mortgages at reasonable interest rates, young white couples could afford to buy houses in suburban developments, but minorities and low-income whites, who were rejected by lenders, continued to reside in rented slum and shanty units. To protect their assets, white homeowners signed covenants prohibiting home sale and rental to minorities, Jews, and some white ethnic groups who, they believed, would lower neighborhood quality and home prices. Even after passage of the Civil Rights Act of 1964, lenders continued to discriminate, not opening branches in minority and low-income white neighborhoods or marketing their services to these groups. Redlining-a mortgage denial practice that took its name from the FHA's red coding of minority neighborhoods and from lender maps with red lines drawn around minority and racially mixed neighborhoods-froze residential segregation and stalled the open housing laws enacted by some municipalities. Under pressure from the Civil Rights movement, Congress passed "the 1968 Fair Housing Act and the 1974 Equal Credit Opportunity Act [which] extended the anti-discrimination principles of civil rights law to housing- and credit-markets, respectively" (Dymski 2009, p. 153). By then masses of white homeowners and realtors, riled by the Brown v. Board of Education (1954) mandate to integrate schools, had fled to the suburbs where a building boom had produced affordable housing and office spaces.

The historical exclusion of women from credit markets continued into the 1980s, owing partly to the failure of the Fair Housing Act (1968) and the Equal Credit Opportunity Act (1974) to monitor and penalize sex discrimination. A single woman-whether never married, divorced, or widowed-needed an adult male relative to co-sign for loans and other types of credit; and when a woman married her credit record (if she had one at all) was subsumed under her husband's name. Ironically, financial institutions considered women to be risky borrowers because of the systemic discrimination-limited employment opportunities, lower wages, and less wealth-to which they themselves contributed. Moreover, haunted by the specter of pregnancy, lenders discriminated against couples when the wife was of child-bearing age, assuming that she would quit her salaried job to be a stay-at-home mother; some lenders actually questioned couples on their use of contraception. ${ }^{2}$

The Civil Rights Act (1964), which prohibited discrimination by organizations receiving federal funds, and Title IX of the Education Amendments Act (1972), which finally added sex discrimination to the protected categories, released pent up complaints and engulfed the Supreme Court in waves of litigation. In "pattern or practice" cases, plaintiffs could present statistical evidence that a policy or practice, even if facially neutral, had a discriminatory impact on them as compared to white and/or male groups (U.S. Department of Justice 2016). But information on mortgage industry discrimination was not collected until the passage of the Home Mortgage Disclosure Act (1975) and even then lenders were not required to report on individual applications until 1989. Studies of mortgage discrimination used audits that matched comparable white and minority borrowers during the prescreening stage and statistical data during the loan applications and default stages. In "Evidence on Discrimination in Mortgage Lending." Helen F. Ladd reviewed academic concerns about whether the many variables and data pool size produced valid findings (Ladd 1998). ${ }^{3}$ Ironically, the fact that big data didn't capture minute variations helped the courts move away from "pattern or practice" evidence.

\section{Extracting Profit from Debt}

Reagan-era deregulation permitted the formerly separated lending, banking, and brokerage firms to expand their activities, develop newly profitable financial instruments, and engage in

2 See (Card 1980) and (Garrison 1976). Today's readers may be incredulous, but I can attest that these discriminatory practices were widespread in the 1970s when as a recently divorced mother of two children I experienced these denials of credit, refused to conscript male relatives, and instead organized women to press for what became a three-day hearing on women and credit in my home state.

3 However, Gary Dymski, whose article foregrounds racial discrimination in the housing and credit industries, argues that some studies definitely confirmed racial discrimination in mortgage lending see (Dymski 2009, pp. 153-54) and elsewhere. 
acquisitions and mergers. ${ }^{4}$ As banks maximized profits by acquiring floundering S\&Ls and developing upscale products to attract wealthy clients, the credit market for unbanked people ballooned. In 2002, according to the General Accounting Office, "28\% of all individuals and $20 \%$ of all households lack[ed] bank-accounts" and were paying billions to alternative financial outlets, such as subprime mortgage lenders and payday stores that gave workers an advance on the next paycheck for extortionist fees ranging from $\$ 18$ per $\$ 100$ and upward. By 2005, 22,000 payday stores were making loans worth $\$ 40$ billion and reaping $\$ 4.4$ billion in fees (Dymski 2009, pp. 157-58, 162-63). Recognizing that low-income people were a lucrative market, mainstream financial institutions acquired these lenders and stores.

\section{Subprime Mortgages}

Originally conceived as a second mortgage for homeowners with prime or near-prime mortgages who needed an infusion of cash to cover an expense or income loss, the subprime mortgage was redesigned for aggressive marketing to minorities, low-income whites, single mothers, veterans, and others deemed unqualified for conventional mortgages. The market took off like a jet plane, fueled by President George W. Bush's promotion of home-owning, a well-stocked housing market, and borrowers' misplaced trust that a house was an ever-appreciating asset from which owners could draw cash, as if from a savings account, for emergency expenses and everyday consumption. ${ }^{5}$ In 2005, subprime mortgages were held by $13.5 \%$ of Asian borrowers, $20 \%$ of white borrowers, $40 \%$ of Latino borrowers, and over $50 \%$ of African American borrowers. ${ }^{6}$ By 2007, total home mortgage debt was dangerously high: of 54.7 million loans for a total debt of $\$ 10$ trillion, $78 \%$ were prime and near-prime mortgages, and the remainder -6.7 million loans for a debt of $\$ 1.2$ trillion-were predatory subprime loans. Of these, $50 \%$ had adjustable interest rates that propelled defaults and, sadly, $20 \%$ were issued to borrowers who could have qualified for prime mortgages. ${ }^{7}$

Knowing at the time that many subprime borrowers would default, lenders tried to protect themselves. To recover some of their investment early on, they front-loaded the mortgages with high fees. To attract wary customers, they offered adjustable rate mortgages (ARMs) with below-market teaser rates that jumped to high interest rates a year or two later (Dymski 2009, pp. 164-65, 171). To take risky debt off their books, bring in new cash, and comply with asset/liability ratios, lenders sold the mortgages to financial institutions that bundled them into securities, in turn sold to banks, private equity firms, hedge funds, state pension plans, and foreign investors. Operating with a moral-hazard mindset, lenders passed the debt to securitizers who passed it to investors who made the fatal mistake of assuming that their investments were tethered to cash flows (borrowers' monthly payments) with underlying assets (houses that could be sold).

The profit-from-debt scheme came to a halt as the effects of default spiraled up the financial chain. Collection firms filed lawsuits against subprime borrowers, again disproportionately racial minorities, who were hit by court-ordered wage garnishment, fines, and jail time; rather than protecting borrowers, collection laws punished them, according to Paul Kiel and Annie Waldman who analyzed court judgments in Chicago, Newark, and St. Louis (Kiel and Waldman 2016). As the rising home foreclosures converged with declining home prices in the overstocked housing market, the revenues

4 For example, see discussion of the Depository Institutions Deregulation and Monetary Control Act of 1980 in (Wyly et al. 2012, pp. 582-84.).

5 (Allon 2010, pp. 375 (on Bush), 366-77 (on home as equity)). Her focus on the 2008 meltdown as caused by moral and regulatory failure and on financialization as a discourse and practice that forms calculating, investing subjects differs from mine on the re-structuring of capital and high-risk securitization.

6 Data reported in (Heintz and Balakrishnan 2012, p. 394).

7 (Frame et al. 2008). I use this document because it was issued at the time of the crisis; on one hand, it shows an awareness of the problems that had been building, and on the other hand it evidences blind spots in hewing to such notions as consumer choice. 
flowing to mortgage-backed securities dried up, leaving investors with losses as well. This brings us to the meta-instruments known as derivatives.

\section{Financialization}

Critical studies describe financialization as an enormous phenomenon operating at warp speed on a global scale. ${ }^{8}$ In The New Imperialism (Harvery 2003), David Harvey's short history of financial capital emphasizes that as industrial and manufacturing companies fled to off-shore locations with cheap labor, multi-national corporations invested surplus capital in speculative financial schemes to enhance their accumulation and maintain U.S. economic dominance once based on material production. Building from Marxist work, Harvey differentiates the earlier forms of accumulation by dispossession - the seizure and commodification of public land, natural resources, private property, and labor power-from the newer forms of accumulation by dispossession through financial instruments of predation, speculation, and outright fraud (Harvery 2005, pp. 62-74, 145-49). More recently in "Debt, Power, and Crisis: Social Stratification and the Inequitable Governance of Financial Markets", James Heintz and Radhika Balakrishnan describe financialization as "the increasing dominance of financial motives, financial institutions (including financial markets), and financial interests," paradoxically enabled by domestic and international regulations that limit the power of governing entities to intervene (Heintz and Balakrishnan 2012, p. 389). Given my focus on structure, I define financialization as an infrastructure-consisting of financial institutions, instruments, and activities - that can override national and international regulatory power in its pursuit of capital surplus, liquidity, and circulation.

\subsection{Derivatives}

In a 2002 letter to investors, Berkshire Hathaway chairman Warren Buffet wrote, "In our view derivatives are financial weapons of mass destruction, carrying dangers that, while now latent, are potentially lethal"(Buffett 2002). Buffet's warning was not as prescient as it might seem, for those who had been tracking the financial industry would have noticed that the conditions for mass destruction already existed-namely, the globalization of finance, competing national regulatory regimes, a shadow banking system of opaque private firms and transactions, perverse incentives toward risk-taking, and the proliferation of derivatives. ${ }^{9}$

Traditional derivatives are commodity-backed forwards, futures, and options. Basically these instruments are contracts between parties who agree "to a price now for a future transaction of the particular commodity"; thus the term "derivatives," according to Dick Bryan and Michael Rafferty in Capitalism with Derivatives, comes from "the idea that the value of the derivative derives from the price of the underlying commodity and was an adjunct to trade in these commodities" (Bryan and Rafferty 2006, pp. 11, 40). Commodity derivatives, such as those backed by wheat, pork, or metals, are said to facilitate trade while reducing exposure to risk: since the production and future pricing of material products are impacted by such variables as weather, access to inputs, and supply/demand, derivatives enable sellers and buyers to stabilize their investments in advance of the actual transaction.

In a wheat forward, a farmer and a miller contract well before harvest time to respectively sell and purchase a specific quantity of wheat at a specific price on a future delivery date. While the forward provides security, it also produces a loser and winner. If the strike price (the contract price) turns out to be lower than the spot price (the market price on the contract's due date), the farmer loses some

8 For critical analyses, see (Calhoun and Derluguian 2011); (Marazzi 2011); (Lazzarato 2011); (Chakravarty and Silva 2012); and (Lazzarato 2015).

9 On mortgage securitization, see (Dymski 2009, pp. 159-62, 172-73); (Major 2012, pp. 547-48); and (Caprio et al. 2010, pp. 125-55). For a readable textbook on derivatives, other instruments, financial markets, credit rating agencies, and regulations, I recommend (Hull 2015). 
profit he could have made and the miller acquires lower-than-market wheat; conversely, if the strike price is higher than the spot price, the farmer receives more than the going rate and the miller is stuck with high-cost wheat (Bryan and Rafferty 2006, pp. 41-42). Futures are contracts sold and bought in exchanges that specialize in certain commodities such as the Chicago Board of Trade in wheat, corn, oats, and rice; the Intercontinental Exchange in coffee, cocoa, cotton, and sugar; and the London Metal Exchange in non-precious metals. Since futures entail the right, but not the obligation, to purchase the commodity, "Delivery typically takes place in cash as the difference between the futures price and the underlying commodity price (or spot price) at the time of settlement" (Bryan and Rafferty 2006, p. 43; LiPuma and Lee 2014, pp. 33-38). If a wheat contract's strike price is $\$ 5000$ for 500 tons of wheat, but the spot price rises to $\$ 6000$, the buyer can take the wheat and pay the seller $\$ 6000$ or refuse the wheat and pay the margin of $\$ 1000$ (Bryan and Rafferty 2006, pp. 12-13, 52-53). By separating the wheat's price change from the actual wheat, the future provides leverage, allowing the buyer to purchase the right to buy wheat more cheaply than actually purchasing the wheat.

Futures speculate on price trends, a characteristic of options as well. The option is a contract that gives the buyer and seller the right, but not the obligation, to complete the transaction. Thus the miller offers the farmer a small payment to induce her to agree to his right to purchase her wheat in the future, but if the price of wheat falls, the miller can back out, lose what he paid for the option, and buy wheat at the cheaper market price (Bryan and Rafferty 2006, pp. 44-45). The cushy stock option offered to corporate executives provides the right to buy a specific number of company shares at a specific per share price. After buying option shares, the executive either sells them when the market price is higher to reap a profit or holds them to reap the dividends. As rationalized, the stock option is said to incentivize the executive to enhance the company's value, but in practice it increases the executive's profit and the company's tax write-down. ${ }^{10}$

A financial derivative reduces assets, such as treasury notes or consumer loans, to attributes; blends assets on the basis of the shared attribute(s) so they can be bundled and sold; and binds the present to the future (Bryan and Rafferty 2006, pp. 12-13, 52-53). Since attributes are abstractions, financial derivatives ratchet speculation up to a meta-level. The investors in these securities do not actually own the treasury notes or loans; rather they receive payouts for their shares of a fund that presumably receives revenues from the notes or loans. Thus risk varies: a developed country like the U.S. is unlikely to default on its treasury notes, but people paying off mortgage, credit card, or auto loan debt do default, causing security revenues to evaporate. Securitizers have attempted to mediate risk by slicing securities into higher risk-higher return tranches and lower risk-lower return tranches, but, as occurred in the subprime debacle, credit rating organizations such as Moody's, Standard and Poor, and Fitch fell down on the job. Although lacking data to evaluate complex derivatives, they were incentivized by lucrative fees to award high ratings. ${ }^{11}$

But even with more accurate ratings, subprime securities would have rippled across the interconnected sectors of the economy. As borrowers defaulted, lenders tried to sell foreclosed homes on the already saturated housing market, slowing sales and decreasing home prices; free-falling home prices put non-defaulting homeowners "under water" with mortgage debt higher than the sale prices

10 Stock options are not very speculative because corporations grant them at very low per share prices and executives can retain them until the market price is high. Among the many concerns about options is whether executives use insider information to anticipate when the market price will rise or actually manipulate the market by announcing good news to make share price rise. See (Hull 2015, p. 356) and (Brooks et al. 2012). Moreover, by writing off the difference between the option price and market price, companies reap billions in tax savings. See (Novack 2013). Option dynamics function somewhat like Marx's $\mathrm{M}^{1} \rightarrow \mathrm{C} \rightarrow \mathrm{M}^{2}$ formula in which a person spends money to produce a commodity that he sells for more money. Both wheat and stock options are commodities with financial value(s) by virtue of being transacted in markets, but the difference is that the farmer produces wheat through his labor, whereas the executive, when hired into his position, receives a potentially profitable commodity irrespective of his future labor.

11 Hull provides an easy explanation of tranches whose simplest structure is tri-partite: the least risky, highest rated, and lowest paying senior tranch, the mezzanine tranch, and the most risky, lowest rated, highest paying equity tranch. In some securities each tranch, though usually the mezzanine tranch, can be sliced into further tranches (Hull 2015, pp. 185-89). Also see (Caprio et al. 2010); and (Major 2012, pp. 547-48). 
they could realize; the super-saturated housing market squeezed home builders, realtors, and home goods retailers; the evaporating mortgage revenue streams caused losses to securitizers and investors; and credit generally froze. Ultimately, the debt was transferred to citizens whose taxes went into the $\$ 700$ billion TARP bailout of many firms that had contributed to the meltdown.

\subsection{Opacity}

The financial system is pockmarked by "black holes." First, credit rating agencies lack the information and tools to evaluate complex derivatives. Second, unlike commodity derivatives traded on exchanges that can be monitored, most financial derivatives are "over the counter" trades (OTCs) among multi-national corporations and financial institutions that are expedited by a dealer or an electronic platform. The magnitude of global OTC trading defies the imagination: the Bank for International Settlements (BIS) estimated outstanding OTC contracts to be $\$ 95$ trillion in December 2002 and daily OTC trading to be \$2.4 trillion in 2005 (Bryan and Rafferty 2006, p. 56). Third, not only OTC trades but also derivatives are "off the balance sheet" transactions (OTBs); since corporations and financial institutions do not include them in their statements of assets and liabilities, the lack of data and the gigantic market size make them impossible to track. Finally, OTC trades, OTB transactions, and the activities of shadowy private equity firms and hedge funds are enabled by international accords and national laws, the latter structuring college student lending in the U.S. ${ }^{12}$

\section{College Student Loans}

In the latter part of the twentieth century, neoliberalism infused the U.S. higher-education system, manifesting itself not only as decreased state funding, earmarked federal funding, rising tuition, corporatized administration, and strategic resource allocation schemes but also as restructured student financial aid. In this section I take a close look at scholarships and loans in order to prepare for the argument that the loan industry is repeating profit-from-debt strategies that caused the 2007-2008 economic crisis.

We do not have precise data on the private and federal loan markets-borrowers, debts, repayments, defaults, and securitizations-because, as Beth Akers and Matthew M. Chingos note, private lenders "do not publish detailed data" and amazingly "the Department of Education only makes available very limited information on federal debt overall" (Akers and Chingos 2016, p. 24). The most reliable information is collected by the Department of Education's National Student Loan Data System (NSDS), which tallies only federal loans but without disaggregating by type of school, campus, and degree program. Inadequate data, along with liberal-individualist logic, predispose many journalists and scholars to write stories about students who are shackled by lifetime debt that prevents them from living independently, rearing families, and buying homes rather than about neoliberal structures. We can speculate, however, about broad impacts by looking at the patterning of loan debt in the context of the education-to-employment pipeline.

\subsection{Student Financial Aid}

During the Reagan era, Congress began shifting federal funding away from college readiness programs (e.g., the TRIO programs for disadvantaged students) and scholarship programs in order to increase student loans and loan industry subsidies. Established by the Higher Education Act of 1965 and renamed to honor Senator Claiborne Pell (Democrat, Rhode Island), the Pell Grant Program was the government's largest provider of college scholarships; yet for three decades Congressional conservatives resisted efforts to increase its grants and operating funds. The purchasing power of grants plunged as college costs rose: in 1975 the maximum grant covered $84 \%$ of the total cost of

12 On OTCs, see (Bryan and Rafferty 2006, pp. 54-64) and (Dodd 2002). 
attending a public university; by 2001 it covered only 39\% of tuition and fees; and in 2016-2017 the maximum grant of $\$ 5700$ (rounded) is expected to cover less than $30 \%$ of tuition and fees. ${ }^{13}$ Overall from 2005 to 2016, Congress reduced program funds by $\$ 50$ billion through such methods as trimming administrative costs, stiffening eligibility requirements, and letting grants lag behind college costs (The Institute for College Access \& Success 2016a). As a share of all federal financial aid, scholarships fell from $55 \%$ in 1979 to $26 \%$ in 2007, while loans rose from $39 \%$ to $64 \%$ during the same period (Best and Best 2014, p. 81).

Explaining the trend to loans, some commentators said that legislators were motivated by cost-effectiveness (since loans were cheaper than grants, they could assist many more students), while others said they were motivated by neoliberal privatization to shift college cost to the students' own resources including loans. In 2010, 67\% of graduating seniors carried an average loan debt of $\$ 25,250$; by $2012,71 \%$ carried an average debt of $\$ 29,400$; and for 2015 , an estimated $68 \%$ carried an average debt between $\$ 30,100$ and $\$ 33,000 .{ }^{14}$ In 2013 , out of 37 million people with college loan debt, 14 million were in the under 30 age group, 10.6 million were in the 30-39 age group, and 12.5 million were spread across the 40 to $60+$ age groups (Student Loan Hero 2014). Although borrowers in the $65+$ group held a small share of total debt, only $\$ 18.2$ billion, $25 \%$ of those from 65 to 75 years old had defaulted and more than $50 \%$ of those over 75 years old had defaulted; both groups were subject to garnishment on their Social Security checks (Lewontin 2014; Martie 2014). Finally, out of the 43 million people carrying loan debt today, $66 \%$ are graduates from public colleges, $75 \%$ are graduates from private colleges, and $88 \%$ are graduates from for-profit colleges (Student Loan Hero 2017; The Institute for College Access \& Success 2013).

These statistics reflect well-known racial and class patterns. Low-income students who disproportionately attend for-profit institutions, two-year colleges, and small private colleges have the greatest need for aid. These students are disproportionately African Americans, Hispanic Americans, single mothers, veterans, and older-than-college-age individuals, most of whom shoulder jobs and family responsibilities. Pell Grants are so inadequate that they compel borrowing: $88 \%$ of Pell Grant recipients have loans for an average of $\$ 31,200$, as compared to $53 \%$ of those without Pell grants whose loans average \$26,450 (Student Loan Hero 2017).

\subsection{Loan Types}

The government's Federal Direct Loan Program (which superseded the Federal Family Education Loans in 2010) provides essentially four types of loans for students who attend accredited colleges at $50 \%$ to $100 \%$ time. For the subsidized Stafford Loans, available to undergraduate students on the basis of financial need, the government pays interest while the student attends college; six months after graduating from or dropping out, the student begins making principal and interest payments on a 10 year repayment plan at a current interest rate of $3.76 \%$. For the unsubsidized Stafford Loans, available to undergraduate students regardless of financial need, the government does not cover interest while the student attends college, thus leaving it to accrue until, six months after graduating or dropping out, students begins making payments at the current interest rate of $3.76 \%$. For Parent PLUS Loans, available to parents of dependent undergraduate students, and Grad PLUS Loans, available to graduate students, the borrower pays all principal and interest during and after college at a current rate of $6.31 \%$. In addition, all borrowers pay origination and serving fees that vary from $1.68 \%$ for subsidized Stafford loans to $4.276 \%$ for Grad PLUS loans. ${ }^{15}$

13 (Office for Civil Rights Staff 2001, p. 106) and (Institute for College Access \& Success 2016a). Also see (Anonymous 2009a) and (Anonymous 2009b).

14 (The Institute for College Access \& Success 2011); (The Institute for College Access \& Success 2013); and (The Institute for College Access \& Success 2016a). The institute, which has released 11 annual reports, provides break-downs by state but tracks only federal loans carried by graduates at nonprofit institutions, although it does include a note with some information on private loans. Minnesota, my state, consistently ranks as the 5th or 6th highest debt state.

15 (The Institute for College Access \& Success 2016b). For 2016-2017 interest rates, see (U.S. Department of Education 2016b). 
The government has accommodation plans for stressed borrowers. Loan Consolidation allows borrowers to merge multiple loans into one loan with a payoff period of 10 to 30 years. Deferment allows them to postpone payments for up to three years if they meet certain criteria, such as active military duty or economic hardship; the government might pay interest for subsidized loans but not for unsubsidized ones. Forbearance is available to borrowers who do not qualify for deferment but meet such criteria as illness or medical internships/residencies; if the borrower does not pay the monthly interest, it accrues to principal thus increasing the monthly payments. Income-Driven Plans adjust payments to post-college income and might offer loan discharge after 20 to 25 years of repayment. Public Service and Teacher Loan Forgiveness allows borrowers in certain jobs to apply for loan forgiveness after 10 years of continuous repayment. ${ }^{16}$

The loans are not as benign as they appear. First, the frustratingly unwieldy application processes for federal and private loans place the onus on potential borrowers to wade through complicated information on eligibility, documentation, and repayment. Second, while federal loan interest rates-3.76\% for Stafford loans and 6.31\% for PLUS loans-seem low compared to private loan rates as high as $13.74 \%$ (October 2016), federal interest is higher than the interest people earn for savings and investments. ${ }^{17}$ A quick Google search (October 2016) shows that institutions paid an average of $1 \%$ for savings accounts, $1.3 \%$ for one-year certificates of deposit, and between $2 \%$ and $3 \%$ for corporate stock dividends-all of which are taxable at the individual's income tax rate. Third, interest compounding in accommodation plans causes debt to balloon in amount and duration. Last, the law prohibits borrowers, even if experiencing severe hardship, from discharging college loan debt through bankruptcy. Essentially we are looking at a power imbalance-namely that individuals generally pay higher interest to borrow private and federal money than private and federal sources pay to borrow individuals' money perhaps because the individual, if rejected, has fewer borrowing choices than institutions which draw revenues from many individual, commercial, and government depositors.

\subsection{Defaults and Collections}

The important fact to remember is that the federal government guarantees federal loans when borrowers default. In its 2016 report, the Consumer Financial Protection Bureau (CFPB) notes that 25\% of federal student loan borrowers were in default or delinquency: eight million borrowers had defaulted, another 650,000 were rehabilitating a defaulted loan by making $\$ 5$ monthly payments, and 230,000 of those in rehabilitation were expected to default for a second time. Moreover, from September 2015 through August 2016, the bureau handled 5500 private student loan complaints, 3900 federal loan servicing complaints, and 2300 debt collection complaints (Consumer Financial Protection Bureau 2016). Among all types of academic institutions, the for-profit sector, which historically has raked in a disproportionately large share of Pell Grants, federal loans, and private loans, has the highest rates of defaults, dropouts, underemployed and unemployed graduates, and fraudulent practices.

Consider some glaring examples. ITT Educational Services, which operated 136 technical schools in 38 states and enrolled more than 35,000 students when it was sued twice-in 2014 by the CFPB for steering students to private loans and misrepresenting their employment prospects; and in 2015 by the Securities and Exchange Commission for concealing losses in its loan programs. A year later, ITT shut down, leaving students to negotiate loan discharges and 8000 employees to look for jobs; but ITT wiggled out of debt by filing for bankruptcy, an option denied to students who cannot pay their debts (McCarthy and Nasiripour 2016, pp. 1-2). While working under contract for the Department of Education (DOE), Navient, the nation's largest loan servicer, was sued by a coalition of 29 state attorneys general for steering desperate borrowers into forbearance and deferment

16 For deferment and forbearance, see (U.S. Department of Education 2016a). For the other plans, see (The Institute for College Access \& Success 2016b).

17 For some facts about private loans which, like subprime mortgages, are targeted to lower-income minorities and whites, see (Institute for College Access \& Success 2016b). 
instead of income-based and forgiveness programs, thus increasing student debts, delinquencies, and defaults (Nasiripour 2016). Another glaring example is detailed in Senator Elizabeth Warren's letter of 29 September 2016 to the Department of Education. More than a year after Corinthian Colleges closed in 2015, "amid findings from state and federal authorities that it had defrauded students over and over again," the DOE had made negligible progress on processing students who were eligible for loan discharges. Out of an estimated 80,000 students, the DOE had provided discharges to 3787 and left the rest mired in aggressive debt collection, "many having their credit slammed, their tax refunds seized, their Social Security and Earned Income Tax Credit (EITC) payments reduced, or their wages garnished"(Warren 2016). Meanwhile, Corinthian discharged its debts through bankruptcy.

A month after receiving Senator Warren's letter, the DOE issued the Borrower Defense Final Regulations to supersede the tangle of state and federal rules on institutional fraud, breach of contract, and misrepresentation. Borrower-helpful provisions include granting loan discharges to groups, not just individuals; extending the statute of limitations for borrower claims; circulating information on risky institutions; and providing students at closed institutions with borrower relief applications and restored Pell Grant eligibility. The regulations also make malfeasant institutions, rather than taxpayers, responsible for loan losses, but how this can be accomplished if for-profit institutions file for bankruptcy is unclear (Thomason 2016).

\section{Speculating on Education Futures}

College financial aid resembles the derivatives market in certain respects. In the college market, diverse investors-students and their families, scholarship donors, lenders, loan securitizers, and security investors-make "spot" investments they hope will yield profits. Based on past experience, they expect the college degree to continue reaping a wage premium as the U.S. transitions to a "new economy" in which intellectual and other innovative labor drive growth in the professional, technological, and business sectors. My argument is they are misinterpreting the signs now, just as they did when they banked on the assumption of ever-increasing home values.

\subsection{Post-Graduate Employment}

What is the likelihood that college graduates will be able to pay down their loans in order to provide liquidity for the profit-from-debt circuit? Unless they are presented with a cash windfall through inheritance or investment, they will depend upon earnings from jobs. According to annual reports issued by the Economic Policy Institute (EPI), the worst rates of unemployment, under-employment, and wage decline occurred in 2010 and 2011 when roughly 30\% of graduates were earning no or low wages as a result of the 2007-2008 economic crisis. EPI's The Class of 2012 shows that among graduates with baccalaureate degrees $9.4 \%$ were unemployed and $19.1 \%$ were under-employed; by race, however, $13.2 \%$ of Hispanic graduates, $10.8 \%$ of Black graduates, and $8.7 \%$ of white graduates were unemployed. ${ }^{18}$ Its latest report, The Class of 2016, shows that among graduates with baccalaureate degrees $5.6 \%$ were unemployed and $12.6 \%$ were underemployed; by race, however, $9.4 \%$ of Black graduates, $6.5 \%$ of Hispanic graduates, and $4.7 \%$ of white graduates were unemployed (Kroeger et al. 2016, pp. 11-13). The situation for 2015 high-school graduates is very grim: $21.2 \%$ of Black graduates, $17 \%$ of Hispanic graduates, and $13.6 \%$ of white graduates were not employed and not attending college (Kroeger et al. 2016, p. 20).

Unsurprisingly wage stagnation retained its grip through the recovery: EPI reports that between 2010 and 2016 wages for high-school graduates declined by $2.5 \%$ and those for college graduates rose by $0.7 \%$. The average wage for high-school graduates was $\$ 10.66$ per hour for an annual income of about $\$ 22,200$, and that for college graduates was $\$ 18.53$ per hour for an annual income of $\$ 38,500$

18 (Schierholz et al. 2012, pp. 9-11). EPI calculates under-employment in hour-based, not skill-based, terms; thus the number of under-employed college graduates would be much higher if those in jobs that did not require a college degree were counted. 
(Kroeger et al. 2016, p. 21). To put these incomes in perspective, the federal poverty line for a family of four (two adults and two children) in 2016 was $\$ 24,300$, a calculation using an outdated 1960s formula that figured the cost of food as $25 \%$ of family income and omitted healthcare, childcare, and other needs. The Family Budget Calculator, a basic needs formula used by many non-governmental organizations, shows that a family of four living in Minneapolis needed $\$ 69,636$ to pay for basic housing, food, transportation, health care, taxes, and childcare (deducting childcare saves \$1300). ${ }^{19}$

Race- and class-patterned unemployment, underemployment, wages, and wealth are effects of the interconnected global and domestic environments manipulated by flourishing multinational businesses. Years ago, innovations in technology and transportation allowed businesses in the industrial, manufacturing, technology, and professional sectors to unbundle work processes, spreading them across distant locations to take advantage of low-wage, low-regulation, and low-tax countries, and then to re-link the process through supply and distribution chains. ${ }^{20}$ The off-shoring of industry, manufacturing, information technology, and call centers is well-known; less well-known is that many professional occupations were also unbundled and off-shored-for instance, such jobs as accounting, architectural drafting, executive assistance, legal writing, medical test analysis and documentation, and pharmaceutical development. These off-shored jobs could have been filled by young Americans with baccalaureate and graduate/professional degrees. ${ }^{21}$ Off-shoring, along with Domestic Right to Work legislation, union-busting tactics, opposition to minimum wage increases and overtime pay, and shrinking worker benefits (if provided at all), deprive American workers of good jobs.

\subsection{The Education-to-Employment Pipeline}

To go further back down the education-to-employment pipeline, let's consider students in elementary, middle, and high schools. For at least a few decades, American K-12 education and higher education, once in first place worldwide, have been sliding down the international rankings. The 2014 reports of the Organization for Economic Co-operation and Development (OECD), which contain comparative data on the prior education of adults, reveal discouraging results. In the U.S., $43 \%$ of the 25-64 year old population had attained higher education, placing it behind Canada at $53 \%$, Russia at $53 \%$, Japan at $47 \%$, and Israel at $46 \%$ (the U.S. figure includes those with two-year college degrees). This fifth place ranking mutes warnings of widening disparity: for the youngest cohort of 25-34 year olds attaining higher education, 11 countries rank above the U.S.; their rate of higher-education attainment by young adults is growing much faster; and their percentage of young adults attaining a higher level of education than their parents is greater, indicating more socioeconomic mobility in these 11 countries than in the U.S. (Organization for Economic Co-operation and Development 2015). Data on primary and secondary education paint a bleaker picture. In 2012 only $38 \%$ of U.S. 3-year-olds were enrolled in early education programs compared to the average of $70 \%$ for all OECD countries; $79 \%$ of U.S. students graduated from upper-secondary schools compared to the average of $84 \%$ for all OECD countries; and salaries for primary-secondary teachers were significantly lower in the U.S. than in most other OECD countries (Organization for Economic Co-operation and Development 2015). Not surprisingly, the OECD notes that low literacy and numeracy skills, which result from low quality primary-secondary education, are concentrated in African-American, Hispanic-American, and (I add) Native-American populations.

American education was and still is patterned by racial and class segregation, funding disparities, and educational inequality. Today public, charter, and private schools are as segregated as schools

19 For the federal poverty line, which is used to determine eligibility for various safety net programs, see (U.S. Department of Health and Human Services 2016). For a realistic family budget adjusted to family make-up and location, see (Economic Policy Institute 2016).

20 For apparel industry off-shoring, see (Whalen 2002); for supply chains, see (Gareffi 2008).

21 See (Hira and Hira 2008); (Korten 2001); and (Reich 2007). These books take a highly critical view of globalizing capital, though like-minded readers will not agree with all positions taken. 
were in the Brown v. Board of Education era. Although scholars disagree on whether the high point in school integration occurred during the 1970s or the 1980s, the story of what sustained segregation and inequality is well known. ${ }^{22}$ It includes demographic trends-great migrations of African Americans to northern cities, Puerto Ricans and Dominicans to the East Coast, Chicanos to the Southwest and West Coast - that triggered white upper- and middle-class flight to the suburbs. It includes discriminatory housing policies and loan practices that sedimented residential segregation. It includes the Supreme Court's turn away from rulings that upheld or ordered remedies for de facto school segregation, such as Milliken v. Bradley (1974) in which the Court ruled that Detroit's de facto segregation based on residential segregation in the metro area did not offend the Constitution.

Perhaps most dispositive today is the conjuncture of pupil assignment to neighborhood schools with funding formulas that build on the bedrock of residential segregation. In this scheme, property-poor districts provide less tax revenue and thus less per capita student funding than property-rich districts do. Since San Antonio Independent School District v. Rodriguez (1973), in which the U.S. Supreme Court ruled that low-income minority and white children had no constitutional right to equal quality education, more than 100 lawsuits challenging school funding schemes have been filed, with roughly two-thirds of the decisions finding for the plaintiff (usually minority and/or low-income children and parents) and one-third finding for the defendant (the state). ${ }^{23}$ But the impact of school funding formulas on educational quality can be grasped only by looking at real-world examples. In Williams v. California, a class-action lawsuit filed in 1997 by the American Civil Liberties Union on behalf of several thousand minority students attending 48 schools in 19 northern California districts, case materials documented a horrifying picture of schools with leaking roofs, broken windows, non-functional HVAC, shuttered bathrooms, rat and mold infestations, unqualified regular and substitute teachers, outdated textbooks, and insufficient supplies. Three years later the case reached a pre-decision settlement that included an elaborate plan for improving school conditions, but subsequent monitoring showed that many of the promised improvements were not made. ${ }^{24}$

The material, instructional, and social inequalities in K-12 education lead to lower achievement rates for many racial minority students and low-income white students, thus disadvantaging these groups for college admission and completion, further graduate and professional education, and of course employment. ${ }^{25}$ These inequalities selectively filter who flows toward a productive future as workers and citizens. But how do they relate to the workings of the neoliberal economy?

\section{Neoliberalism}

Recall that the economy tanked in 2007-2008 as subprime mortgage defaults rippled through the interconnected financial infrastructure, harming the housing market, homebuilding trades, realty firms, mortgage companies, securitizers, and ultimately security investors. In a 2014 article for credit.com, Mitchell D. Weiss wrote about securitized college student loans, called student loan asset-backed bonds (SLABs), with more enthusiasm than one would expect of a former financial industry executive now located in academe.

22 In (Johnson, Jr. 2014), Odis Johnson, Jr. believes that desegregation efforts peaked during the Nixon-Ford administrations (1969-1977), driven by waves of Supreme Court rulings in desegregation cases following the Civil Rights Act of 1964 In (Civil Rights Project 2016), Gary Orfield, Jongyeon Ee, Erica Frankenberg, and Genevieve Siegal-Hawley place the high point at 1988 (both articles are focused on integration of African-American students, not other groups). The Civil Rights Project, founded by Orfield and Christopher Edley, Jr. at Harvard in 1996 and relocated at UCLA in 2007, is a treasure trove of data and publications on the many aspects of educational segregation and inequality.

23 For information on school inequality and litigation, see Education Law Center at http:/ / edlawcenter.org; and SchoolFunding. Info at schoolfunding.info.

24 See, for instance, (Oakes and Lipton 2004).

25 Sadly, the NAACP Education Department's 2002 report still provides the gold-standard overview of race- and class-patterning in pre-school, primary, secondary, and higher education. See (Jackson and Smith 2002). Sadly, too, I see by the card clipped to my copy that it was given to me by the then chair of the NAACP, Julian Bond, who passed away in August 2015. 
Student loans are an interesting anomaly. The financings are uncollateralized (how can you repossess an education?) and the credit profiles of most of the borrowers are weak (how many 18-year-olds with stellar credit histories do you know?). Yet, these transactions are exceedingly attractive to the investment community for two very good reasons. Foremost, most of the loans are guaranteed by the federal government, which pretty much ensures that the investors won't take a hit if the borrowers default. Second, even if the loans weren't backstopped by the feds, the debts are virtually impossible to elude in bankruptcy court, which means they'll probably liquidate over time. ${ }^{26}$

Taking the short-sighted view of investor protections, such as they are, he missed the larger picture: a rippling crisis can be averted only if sufficient capital to cover loan debt is available to lenders in the form of continuing revenues, to workers in the form of earnings, and to government in the form of undedicated tax revenues.

\subsection{Securitization}

Today, half of the $\$ 1.3$ trillion in student loan debt is in repayment over a 25 -year timeline, but in order to continue issuing loans and paying their operating costs lenders must replenish their revenues by selling their loans to securitizers. As significant numbers of the underlying loans go into delinquency, default, forbearance, deferment, and discharge, SLAB revenues will start evaporating; the major securitizers-Sallie Mae, Navient, Nelnet, and the suspiciously undisciplined start-up firms that recently entered the securitization market-will turn to the federal government for the promised backstopping. This scenario is already underway for SLABs consisting of federal loans issued under the pre-2010 Federal Family Education Loan Program (FFELP). Allison Bisbey and Nora Colomer's article for American Banker estimates that 15\% of FFELP borrowers are in income-based repayment, and $75 \%$ of these borrowers are paying only interest or nothing at all; moreover, 3.9 million of Federal Direct Loan Program (FDLP) borrowers were enrolled in income-based repayment plans. These figures do not include all FFELP and FDLP defaults, forbearances, deferments, and discharges given to students bilked by for-profit institutions. Bisbey and Colomer note that "Moody's believes that FFELP bonds could default, beginning with those maturing in 2018 and 2019" (Bisbey and Colomer 2016, p. 5). Indeed in April 2014 Moody's completed a year-long study of the debt held by Navient, substantially downgrading its $\$ 130$ billion portfolio of FFELP and private college student loans, much of which had been securitized.

To supply a little history, neoliberal government has blurred the lines between federal and private lending. Sallie Mae, a government-sponsored enterprise, used to originate and service federal student loans, but when it was privatized in the late 1990s it became the SLM Corporation, which in turn housed Navient as a subsidiary. When Moody's downgraded Navient, the SLM Corporation

restructured its business into two separate independent companies-Navient, Corp. and SLM Corp. Navient, Corp., the parent of Navient, LLC, retains all of the former company's non-bank FFELP and private education loan portfolios, student loan servicing operations, and collections business, as well as all of the obligations on the former company's outstanding senior unsecured debt. The new SLM Corp., retains the former company's banking operations, private student loan origination business and UPromise Rewards program (Moody's Investors Service 2016).

26 (Weiss 2016). Weiss's website portrays him as a former executive at commercial financial institutions who holds a residency at the University of Hartford where he was co-founder of its Center for Personal Financial Responsibility ("Get to Know Mitchell D. Weiss." accessed on 17 September 2016 at http:/ / mitchelldweiss.com/author.php). For a diametrically opposing critical analysis, see (Soederberg 2016). She argues that the commodification of student debt operates the same way that as the commodification of subprime mortgages, except that the government is more entangled in the former. She gives the name "debtfare state" to neoliberal institutions that discipline all but the wealthiest Americans through the profit-from-debt regime, forcing them to depend upon expensive credit to meet their basic needs (Soederberg 2016, pp. 5-6). 
SLM thus sought higher ratings by shoveling its risky debt into a now completely separate company but continued to securitize loans. A recent visit to SLM's website reveals that in November 2016 it listed seven SMB Private Education Loan Trusts from 2014 through 2016, each one consisting of about $\$ 657$ million in private loans (Sallie Mae 2016).

In view of the rating agencies' failures to accurately rate securitized subprime mortgages, what do their ratings of securitized student loans mean? Moody's report announcing its downgrading of Navient debt is a masterpiece of rhetorical deniability, in several places stating that credit ratings issued by Moody's are its "CURRENT OPINIONS OF THE RELATIVE FUTURE CREDIT RISK" and "ARE NOT STATEMENTS OF CURRENT OR HISTORICAL FACT" (its capitalization, my underlining). The report goes on to say that Moody's is not responsible for data errors and, to the extent permitted by law, for any investor losses (Moody's Investors Service 2016). Moody's elevation of opinions and elimination of facts to deflect responsibility recall not only the fraudulent practices of predatory subprime lenders and for-profit marketers but also the fact-free zone inhabited by the current Executive Branch.

Understandably nervous about college loan defaults and accommodation plans for stressed borrowers, investors have begun selling their shares, lowering SLAB prices and starting to glut the market. In view of defaults and sell-offs, the steps taken by the financial industry can only be described as anemic: Moody's and Fitch downgraded some SLABs; Navient and others are buying back shares in some SLABs and repackaging others in tranches; and a few securitizers are looking for ways to speed up investor repayment (Bisbey and Colomer 2016). But the profit-from-student-debt circuit could freeze up if lenders have trouble selling to securitizers who in turn have trouble selling to investors.

\subsection{The Neoliberal Architecture}

In "Neoliberalism and the New International Financial Architecture" (Major 2012), Aaron Major looks at the Basel Capital Accord (1988), which "was rooted in the principle of 'home country control', whereby national regulatory bodies and private financial institutions would be responsible for the implementation of internationally negotiated banking standards and for monitoring their own banks' compliance with these standards" (Major 2012, p. 565). Among the standards left to the home country were the ratios of solid assets to risky assets and debt that an institution needed to maintain. Institutions could evade these standards through unmonitored over-the-counter trades, off-the-balance-sheet transactions, and capital migration. The U.S. tax code encourages capital migration in various ways, one of which is that corporations can defer paying taxes on foreign-earned income as long as they do not repatriate the money-e.g., use it to invest, cover expenses, or pay dividends in the U.S. ${ }^{27}$ According to a 2016 study, multinational companies held a total of $\$ 2.5$ trillion in off-shore tax havens (Citizens for Tax Justice 2016). But by depositing foreign-earned income in multinational banks with headquarters or major branches in the U.S., they could by proxy circulate the money in the U.S. as well as abroad. What is not returned to the U.S. is the tax on profit, estimated to be $\$ 50$ billion annually and \$265 billion from 2013 to 2017 (Richards and Craig 2015).

Another way to avoid taxes and circulate capital is inversion. In 2014, Medtronic, a medical device company historically located in Minneapolis, spent $\$ 42.9$ billion to acquire Covidien PLC, a company that derives most of its revenues from U.S. sales but is incorporated in Ireland where the on-the-books tax rate is $7.9 \%$ compared to the on-the-books rate of $35 \%$ in the U.S. (on average, 288 Fortune 500 companies actually paid at the much lower rate of $19.4 \%$ for 2008 through 2012). ${ }^{28}$ When Medtronic relocated its headquarters to Ireland, it saved on not only future U.S. taxes but also U.S. taxes on the

27 (Richards and Craig 2015). James S. Henry estimates that "as of 2015, they [tax havens] hold at least $\$ 24$ trillion to $\$ 36$ trillion in anonymous private financial wealth" that is not taxed in the individuals' home countries. In the US big-name financial conglomerates-Bank of America, Citigroup, Goldman Sachs, JPMorgan Chase, Morgan Stanley, and Wells Fargo-arrange for wealth migration. See (Henry 2016).

28 See (McIntire et al. 2014). Out of the 288 corporations reviewed for their report, 111 paid no taxes or received refunds in at least one of the five years surveyed. In other words, this cohort of highly profitable corporations pays at tax rates comparable to those of poor, low-income, and middle-income Americans. 
\$20.5 billion it had already stockpiled off-shore. Paradoxically, this inversion deal triggered a tax event for shareholders, including retirees with small holdings in their retirement accounts. While they paid the capital gains tax, Medtronic helpfully covered the taxes of its own executives. In 2014 Bloomberg estimated that American companies were sheltering more than $\$ 1.95$ trillion in offshore businesses (Midler 2014).

In short, the Basel Accord and the U.S. tax code encourage multinationals to engage in opaque transactions, capital migration, and tax avoidance while continuing to wring profits from U.S. consumers and taxes from ordinary citizens. Today (2016) the federal debt of $\$ 19.8$ trillion does not include the estimated state debt of $\$ 1.2$ trillion, the unfunded mandates like Social Security and Medicare, or the guaranteed backstopping of about $90 \%$ of the $\$ 1.3$ trillion in college student loan debt. ${ }^{29}$ How could the government-which is starved of taxes on off-shored corporate profits but now promising to increase the defense budget and pay for much-needed infrastructure repair-actually back-stop rising loan defaults? Failure to pay up would result in a global loss of faith in the U.S. economy, but paying up would require massive cuts to safety net programs, health care programs, education and research, civil service, and block grants to the states. Such downsizing would ripple through the employment sectors, depriving many Americans of their jobs and many businesses of their sales. Once the multi-nationals have drained the majority of our resources, they will move on to exploit the lucrative consumer markets they now are developing elsewhere.

Acknowledgments: Thanks to Libby Arendt for directing me to Moody's disclaimers and Medtronic's inversion; to David Lemke for research assistance; and to Andrew Elfenbein, Ron Strickland, and the reviewers for their readings.

Conflicts of Interest: The author declares no conflict of interest.

\section{References}

Akers, Beth, and Matthew M. Chingos. 2016. Game of Loans: The Rhetoric and Reality of Student Debt. Princeton: Princeton University Press, p. 63.

Allon, Fiona. 2010. Speculating on Everyday Life: The Cultural Economy of the Quotidian. Journal of Communication Inquiry 34: 376-77. [CrossRef]

Anonymous. 2009a. For Many Years GOP Senators Have Consistently Opposed Pell Grants: A Vital Program For the Higher Education of African Americans. Journal of Blacks in Higher Education 65: 6-9.

Anonymous. 2009b. Special Report: Pell Grants: The Cornerstone of African-American Higher Education. Journal of Blacks in Higher Education 65: 70-79. [CrossRef]

Best, Joel, and Eric Best. 2014. The Student Loan Mess: How Good Intentions Created a Trillion-Dollar Problem. Berkeley: University of California Press, p. 81.

Bisbey, Allison, and Nora Colomer. 2016. The Unintended Consequences of a Student-Loan Fix. American Banker. Available online: www.americanbanker.com/news/consumer-finance/the-unintended-consequences-ofa-student-loan-fix/1076566-1.html (accessed on 16 September 2016).

Brooks, Robert, Don M. Chance, and Brandon Cline. 2012. Private Information and the Exercise of Executive Stock Options. Financial Management 3: 733-64. [CrossRef]

Bryan, Dick, and Michael Rafferty. 2006. Capitalism with Derivatives: A Political Economy of Financial Derivatives, Capital and Class. Houndsmill: Palgrave Macmillan.

Buffett, Warren. 2002. Berkshire Hathaway Chairman's Letter to Shareholders. Available online: http:/ /www. berkshirehathaway.com/letters/2002pdf.pdf (accessed on 3 April 2015).

Calhoun, Craig, and Georgi Derluguian. 2011. Business as Usual: The Roots of the Global Financial Meltdown. New York: New York University press and Social Science Research Council.

Caprio, Gerard, Asli Demirgüç-Kunt, and Edward J. Kane. 2010. The 2007 Meltdown in Structured Securitization: Searching for Lessons, not Scapegoats. The World Bank Research Observer 25: 125-55. [CrossRef]

29 For federal debt, see (US Government Debt 2016) for Debt and Deficits. 
Card, Emily. 1980. Women, Housing Access, and Mortgage Credit. Signs: Journal of Women in Culture and Society 5: 215-19. [CrossRef]

Chakravarty, Paula, and Denise Ferreira de Silva. 2012. Race, Empire, and the Crisis of the Subprime. Baltimore: Johns Hopkins University Press.

Citizens for Tax Justice. 2016. News Release: 367 Fortune 500 Companies Collectively Maintain 10,366 Tax Haven Subsidiaries. Available online: http://ctj.org/ctjreports/2016/10/news_release_367_fortune_500_companies_ collectively_maintain_10366_tax_haven_subsidiaries.php\#.WONNC2f-upo (accessed on 6 October 2016).

Civil Rights Project. 2016. Brown at 62: School Segregation by Race, Poverty, and State. Available online: https: / civilrightsproject.ucla.edu/research/k-12-education/integration-and-diversity/brown-at-62-schoolegregation-by-race-poverty-and-state (accessed on 20 October 2016).

Consumer Financial Protection Bureau. 2016. Annual Report of the CFPB Student Loan Ombudsman. Available online: http:/ / files.consumerfinance.gov/f/201510_cfpb_annual-report-of-the-cfpb-student-loanombudsman.pdf (accessed on 18 October 2016).

Dodd, Randall. 2002. The Structure of OTC Derivatives Markets. The Financier 9: 1-5.

Dymski, A. Gary. 2009. Racial Exclusion and the Political Economy of the Subprime Crisis. Historical Materialism 17: 157-58. [CrossRef]

Economic Policy Institute. 2016. Family Budget Calculator. Available online: http:/ /www.epi.org/resources / budget/ (accessed on 6 November 2016).

Foroohar, Rana. 2016. Makers and Takers: The Rise of Finance and the Fall of American Business. New York: Crown Business, p. 9.

Frame, Scott, Andreas Lehnert, and Neil Prescott. 2008. A Snapshot of Mortgage Conditions with an Emphasis on Subprime Mortgage Performance. Federal Reserve Online. Available online: http:/ / federalreserveonline.org/ pdf/MF_Knowledge_Snapshot-082708.pdf (accessed on 18 October 2016).

Gareffi, Gary. 2008. The Organization of Buyer-Driven Global Commodity Chains: How U.S. Retailers Shape Overseas Production Networks. In The Transnational Studies Reader. Edited by Sanjev Khagran and Peggy Levitt. New York: Routledge, pp. 429-45.

Garrison, L. Martha. 1976. Credit-ability for Women. The Family Coordinator 25: 241-48.

Gordon, Adam. 2005. The Creation of Home Ownership: How New Deal Changes in Banking Regulation Simultaneously Made Homeownership Accessible to Whites and Out of Reach for Blacks. Yale Law Journal 1: 192-93.

Harvery, David. 2003. The New Imperialism. Oxford: Oxford University Press.

Harvery, David. 2005. The New Imperialism. Oxford: Oxford University Press.

Heintz, James, and Radhika Balakrishnan. 2012. Debt, Power, and Crisis: Social Stratification and the Inequitable Governance of Financial Markets. American Quarterly 64: 387-409. [CrossRef]

Henry, S. James. 2016. Taxing Tax Havens: How to Respond to the Panama Papers. Foreign Affairs. Available online: https:/ / www.foreignaffairs.com/articles.panama/2016-04-12/taxing-tax-havens (accessed on 8 October 2016).

Hira, Ron, and Anil Hira. 2008. Outsourcing America: The True Cost of Shipping Jobs Overseas and What Can Be Done About It. New York: American Management Association.

Hull, C. John. 2015. Options, Futures, and Other Derivatives, 9th ed. Boston: Pearson.

Institute for College Access \& Success. 2016. Pell Grants Help Keep College Affordable for Millions of Americans. Available online: http:/ /www.ticas.org/content/pub/pell-grants-help-keep-college-affordable-millionsamericans (accessed on 8 September 2016).

Institute for College Access \& Success. 2016. Private Loans: Facts and Trends. Available online: www.ticas.org/ content/pub/private-loans-facts-and-trends-0 (accessed on 8 October 2016).

Jackson, H. John, and Maxine Smith. 2002. NAACP Call For Action In Education. Washington: NAACP.

Johnson, Odis, Jr. 2014. Still Separate, Still Unequal: The Relation of Segregation in Neighborhoods and Schools to Education Inequality. Journal of Negro Education 83: 199-215. [CrossRef]

Kiel, Paul, and Anna Waldman. 2016. The Color of Debt: How Collection Suits Squeeze Black Neighborhoods. Available online: https:/ /www.propublica.org/article/debt-collection-lawsuits-squeeze-black-neighborhoods (accessed on 18 October 2016).

Korten, C. David. 2001. When Corporations Rule the World, 2nd ed. Bloomfield: Kumarian Press and San Francisco: Berrett-Koehler. 
Kroeger, Teresa, Tanyell Cooke, and Elise Gould. 2016. The Class of 2016. Available online: http:/ / www.epi.org/ publication/class-of-2016/ (accessed on 18 October 2016).

Ladd, F. Helen. 1998. Evidence of Discrimination in Mortgage Lending. Journal of Economic Perspectives 12: 41-62. [CrossRef]

Lazzarato, Maurizio. 2011. The Making of the Indebted Man: An Essay on the Neoliberal Condition. South Pasadena, CA: Semiotext(e).

Lazzarato, Maurizio. 2015. Governing by Debt. South Pasadena: Semiotext(e).

Lewontin, Max. 2014. Student-Loan Debt Skyrockets for Elderly, Government Report Says. Chronicle of Higher Education. Available online: http://chronicle.com/article/Student-Loan-Debt-Skyrockets/148755/ (accessed on 3 March 2015).

LiPuma, Edward, and Benjamin Lee. 2014. Financialization and the Globalization of Risk. Durham: Duke University Press, pp. 33-38.

Major, Aaron. 2012. Neoliberalism and the New International Financial Architecture. Review of International Political Economy 19: 547-48. [CrossRef]

Marazzi, Christian. 2011. The Violence of Financial Capitalism, 2nd ed. Translated by Kristina Lebedova, and Jason Francis McGimsey. Los Angeles: Semiotext(e).

Martie, Jonnelle. 2014. More seniors are carrying loan debt into retirement. The Washington Post. Available online: https:/ /www.washingtonpost.com/news/get-there/wp/2014/09/11/more-seniors-are-carryingstudent-loan-debt-into-retirement/?utm_term=.0514aec1930e (accessed on 28 March 2015).

McCarthy, Dawn, and Shahien Nasiripour. 2016. ITT Educational Services Files for Bankruptcy After Shutdown. Bloomberg News. Available online: http:/ /www.bloomberg.com/news/articles/2016-09-16/itt-educationalservices-files-for-bankruptcy-after-hutdown-it6byu6t (accessed on 24 October 2016).

McIntire, S. Robert, Matthew Gardner, and Richard Phillips. 2014. The Sorry State of Corporate Taxes: What Fortune 500 Firms Pay (or Don't Pay) in the USA and What They Pay Abroad-2008-2012. Washington: Citizens for Tax Justice.

Midler, R. Zachary. 2014. Medtronic Is Biggest Yet to Renounce U.S Tax Citizenship. Bloomberg News. Available online: http:/ / www.bloomberg.com/news/articles/2014-06-16/medtronic-is-biggest-firm-yetto-renounce-u-s-tax-status (accessed on 28 October 2016).

Moody's Investors Service. 2016. Rating Action: Moody's concludes review of SLM Corp. Available online: https://www.moodys.com/research/Moodys-concludes-review-of-SLM-Corp--PR_297781 (accessed on 7 November 2016).

Nasiripour, Shahien. 2016. America's Largest Student Loan Firm Abused Borrowers And Broke The Law, Officials Say. Huffington Post. Available online: http:/ /www.huffingtonpost.com/entry/state-prosecutors-navient_ us_57214218e4b01a5ebde47a02 (accessed on 25 October 2016).

Novack, Janet. 2013. Stock Options Meant Big Tax Savings For Apple and JPMorgan, As Well As Facebook. Forbes. Available online: http:/ /www.forbes.com/sites/janetnovack/2013/04/24/stock-options-meant-big-taxsavings-for-apple-and-jp-morgan-as-well-as-facebook/\#24a0a3bf2503 (accessed on 25 October 2016).

Oakes, Jennifer, and Martin Lipton. 2004. Schools That Shock the Conscience: Williams v. California and the Struggle for Education on Equal Terms Fifty Y ears after Brown. Berkeley Journal of African-American Law \& Policy 152: 152-76.

Office for Civil Rights Staff. 2001. Beyond Percentage Plans: The Challenge of Equal Opportunity in Higher Education; Washington: U.S. Commission on Civil Rights, p. 106.

Organization for Economic Co-operation and Development. 2015. Country Note, Education at a Glance 2014: United States. Available online: https:/ /www.oecd.org/unitedstates/United\%20States-EAG2014-CountryNote.pdf (accessed on 1 April 2015).

Reich, B. Robert. 2007. Supercapitalism: The Transformation of Business, Democracy, and Everyday Life. New York: Knopf. Richards, Kitty, and John Craig. 2015. Offshore Corporate Profits: The Only Thing 'Trapped' is Tax Revenue. Available online: https://www.americanprogress.org/issues/economy/report2014/01/09/81681/offshorecorporate-profits-the-only-thing-trapped-is-tax-revenue (accessed on 6 October 2015).

Sallie Mae. 2016. Asset-Backed Securities; SMB Private Education Loan Trusts. Available online: https://www. salliemae.com/about/investors/Asset-Backed-Securities/default.aspx (accessed on 22 November 2016).

Schierholz, Heidi, Natalie Sabadish, and Hilary Wething. 2012. The Class of 2012: Labor Market for Young Graduates Remains Grim. Washington: Economic Policy Institute. 
Soederberg, Susanne. 2016. The Student Loan Crisis and the Debtfare State. Dollars E Sense. Available online: http:/ / dollarsandsense.org/archives/2015/0515soederberg.html (accessed on 28 October 2016).

Student Loan Hero. 2014. Student Loan Debt Statistics-American Student Assistance Accessed. Available online: https:/ / perspectivebypaul.wordpress.com/2013/11/15/student-loan-debt-statistics-american-studentassistance/ (accessed on 2 January 2014).

Student Loan Hero. 2017. A looking at the Shocking Student Loan Debt Statistics for 2017. Available online: https: / studentloanhero.com/student-loan-debt-statistics (accessed on 4 April 2017).

The Institute for College Access \& Success. 2011. Student Debt and the Class of 2010. Available online: http: / / ticas.org/sites/default/files/pub_files/classof2010.pdf (accessed on 18 October 2016).

The Institute for College Access \& Success. 2013. Student Debt and the Class of 2012. Available online: www.ticas. org/content/pub/student-debt-and-class-2012 (accessed on 18 October 2016).

The Institute for College Access \& Success. 2016a. Student Debt and the Class of 2015. Available online: http:/ / ticas.org/content/pub/student-debt-and-class-2016 (accessed on 18 October 2016).

The Institute for College Access \& Success. 2016b. Federal Student Loan Amounts and Terms for Loans Issued in 2016-17. Available online: www.ticas.org/sites/default/files/pub_files/loan_terms_2016-17.pdf (accessed on 12 October 2016).

Thomason, Andy. 2016. Education Dept. Details New Measures on How Defrauded Borrowers Can Seek Relief. Chronicle of Higher Education. Available online: http://www.chronicle.com/blogs/ticker/education-deptdetails-new-measures-on-how-defrauded-borrowers-can-seek-relief/115295?cid=at\&utm_source=at\&utm_ medium=en\&elqTrackId=c35f66d8617c41bb8b5bde9636d23f73\&elq=42bed4d9df2646d5b804fa5db82fc086\& elqaid=11286\&elqat=1\&elqCampaignId=4374 (accessed on 29 October 2016).

U.S. Department of Education. 2016a. A Deferment Or Forbearance Allows You To Temporarily Postpone Making Your Federal Student Loan Payments Or To Temporarily Reduce The Amount You Pay. Available online: https:/ / studentaid.ed.gov/sa/repay-loans/deferment-forbearance (accessed on 12 October 2016).

U.S. Department of Education. 2016b. Federal Student Aid. Available online: https://studentaid.ed.gov/sa/ types/loans/interest-rates (accessed on 12 October 2016).

U.S. Department of Health and Human Services. 2016. Poverty Guidelines. Available online: https://aspe.hhs. gov/poverty-guidelines (accessed on 6 November 2016).

U.S. Department of Justice. 2016. A Pattern or Practice of Discrimination. Available online: https://www.justice. gov/crt/pattern-or-practice-discrimination (accessed on 9 September 2016).

U.S. Government Department. 2016. Debt and Deficits. Available online: http://www.usgovernmentdebt.us (accessed on 21 October 2016).

Warren, Elizabeth. 2016. US Senator ElizabethWarren to John B. King, Jr. Available online: http:/ /www.warren. senate.gov / files / documents/2016-9-29_Letter_to_ED_re_Corinthian_data.pdf (accessed on 5 October 2016).

Weiss, D. Mitchell. 2016. There's a Better Way to Securitize Student Loans. Available online: http:/ /blog.credit. com/2014/01/theres-a-better-way-to-securitize-student-loans-74443/ (accessed on 16 September 2016).

Whalen, Teresa Carmen. 2002. Sweatshops Here And There: The Garment Industry, Latinas, and Labor Migrations. International Labor and Working Class History 61: 45-68. [CrossRef]

Wyly, Elvin, C. S. Ponder, Pierson Nettling, Bosco Ho, Sophie Ellen Fung, Zachery Liebowitz, and Dan Hammel. 2012. New Racial Meanings of Housing in America. American Quarterly 64: 582-84. [CrossRef]

(C) 2017 by the author. Licensee MDPI, Basel, Switzerland. This article is an open access article distributed under the terms and conditions of the Creative Commons Attribution (CC BY) license (http:/ / creativecommons.org/licenses/by/4.0/). 